\title{
A hazai pálya előnye A társas kapcsolatok szerepe a falusi fiatalok immobilitásában
}

\author{
HUSZTI ÉVA ${ }^{1}$
}

\begin{abstract}
ABSZTRAKT
A tanulmány az egyéni network felépítésének, múködésének hatását vizsgálja a falusi fiatalok immobilitására. A tanulmány alapjául szolgáló kutatás 2018-ban, 2500 fö alatti településen élö, 19-25 év között falusi fiatalok körében zajlott strukturált interjúk készítésével. A kutatás keretében összesen 104 interjú készült 53 fiatal és 51 szülő részvételével. A tanulmányban elsőként a kutatás alkalmával megkérdezett fiatalok személyes kapcsolathálózatának kiterjedtsége, összetétele kerül ismertetésre, majd a fiatalokat körülvevő társas kapcsolatok feltárt funkcióinak az immobilitásra gyakorolt lehetséges hatásait kerülnek bemutatásra. Az interjúk alapján elmondható, hogy a vizsgált fiatalok személyes kapcsolathálózata az erôs, elsősorban közeli családtagokból, rokonokból áll. A gyenge kötések közül leginkább az oktatási intézményekhez (általános iskola, középiskola, egyetem) kötődő kapcsolatok vannak jelen a fiatalok networkjében. Az adatok alapján megfigyelhetö, hogy a helyi oktatási intézményeknek nagy szerepe van a barátságok kialakulásában. A falun belüli munkahelyi kapcsolatok, szomszédok, ismerösök nem általános aktorai a megkérdezettek kapcsolathálózatának.
\end{abstract}

KULCSSZAVAK: egyéni kapcsolathálózat, immobilitás, falusi fiatalok, erős kötések, gyenge kötések

\section{ABSTRACT}

\section{Advantages of the home ground}

The role of the social contacts in the immobile status of the rural youth

The paper deals with the effects of the structure and the working of the egocentric network to the immobile status of rural youth. The research was made in 2018 among 19-25-year-old youth living in villages with not more than 2500 inhabitants. More, than a hundred (104) structured interview was made: 53 youth and 51 parents. Firstly, the study shows the network size and composition of the examined population, then the influence of the revealed functions of the egocentric network of the youth to their immobility. Based on the data the egocentric network of the youth mainly consist of strong ties: close kin and other relatives. From the weak ties the most frequent contacts belong to the education institutions as primary or grammar school, university.

\footnotetext{
${ }^{1}$ Szociológus, főiskolai docens, Debreceni Egyetem Egészségügyi Kar, huszti.eva@foh.unideb.hu
} 


\section{TEMATIKUS TANULMÁNYOK - Községekben élő immobil fiatalok}

The local schools have a great role in the forming of the friendships. The local working place contacts, neighbours and acquaintanceships are not general actors of the egocentric networks of the youth.

KEYWORDS: egocentric social network, immobile status, rural youth, strong ties, weak ties.

„Pesten azért láttam, hogy mi megy, hogy mindenki csak így megy. Aztán itt azért kicsit barátságosabb a közeg. Meg hát ugye csak itt nöttem fel. Hazai pálya."

(24 éves nő)

\section{Bevezetés}

Az egyént körülvevő személyeknek, a társaknak fontos szerepe van a társadalmi integrációban, a minőségi élet kialakításában, a társadalmi mobilitásban. Meglétük érvényre jut az elérhető erőforrások mozgatásában, az egyénnek a társadalomba való beágyazódottságában (social embeddedness). Ezekre a kapcsolatokra, az így összeállt kapcsolati tőkére bármilyen társadalmi pozícióban lévő egyénnek szüksége van. A társadalmi hierarchia alján lévő csoportok körében a mindennapos megélhetés biztosításában is kiemelkedő szerepe van a rokonok, barátok, szomszédok által alkotott természetes védőhálónak (Vastagh - Huszár 2008). Az egyéni kapcsolathálózat az egyén és a társadalom közötti „mezo” szinten működik. Ez a működés abban érhető tetten, ahogyan az egyén személyes networkjén jut el különböző javakhoz, forrásokhoz, csoportokhoz, intézményekhez (Bidard 2006, Albert - Dávid Gerő - Hajdú 2017). Bourdieu, illetve Coleman társadalmi tőkének nevezi ez a típusú erőforrást (Bourdieu 1986, Coleman 1988).

A személyes kapcsolathálózat részletesebb feltárásával ahhoz a kérdéshez szeretnék közelebb kerülni, hogy miért nem hagyták el falujukat a vizsgált fiatalok? Mennyire játszik szerepet immobilitásukban az, hogy a falusi közösség biztonságot, kiszámíthatóságot nyújt a bizonytalansággal szemben? Mennyire vannak jelen a fiatalok otthonmaradás melletti döntésében a lokális szolidaritás hálón keresztül elérhető és mozgósítható javak, melyek a posztadoleszcens utáni önálló fiatal felnőtt lét kialakulásában nyújthatnak támogatást?

A legutóbbi ifjúságkutatás (MIK 2016) eredményei szerint a fiatalok az ifjúság egyik legégetőbb problémájának a kilátástalanságot, illetve az anyagi nehézségeket tartják. A kilátástalanság megítélése az észak-alföldi és észak-magyarországi régiókban átlagos, az anyagi nehézségek pedig átlagon felüli értékeket mutattak az ifjúságkutatás során. Érdemes megemlíteni, hogy a két régióban a kapcsolati nehézségek, 


\section{TEMATIKUS TANULMÁNYOK - Községekben élő immobil fiatalok}

mint probléma megjelölése is gyakoribb, mint az ország többi régiójában. Az egzisztenciális problémákat inkább a vidéki nagyobb városokban, az anyagi nehézségeket viszont a falusi fiatalok érzékelték nagyobb arányban. A kapcsolati nehézség, mint probléma észlelése a falusi fiatalok körében kevéssé jelentős, mint más településtípusokon. A függetlenedési folyamatot a falvakban élő fiatalok lényegesen kevéssé élik meg problémaként, mint akár a fővárosi, akár a megyeszékhelyeken élők (Fazekas - Nagy - Monostori 2018).

Az interjúkérdésekre adott válaszok alapján a tanulmány többek között foglalkozik azzal a kérdéssel is, hogy a falusi közösségben könnyen elérhető, mobilizálható erőforrások mennyire pótolhatják az egyébként nem, vagy csak nehezen elérhető erőforrásokat (elsősorban anyagi vagy más materiális javak, illetve információk).

\section{Az egyéni kapcsolathálózat általános jellegzetességei}

Az erős kapcsolatok a mindennapi, többnyire intenzív, intim kapcsolatok, melyek elsősorban a szúk család (szülők, gyerekek, házastársak, testvérek) tagjai. Itt említjük a közeli rokonságot, illetve a közeli, bizalmas barátokat is, akivel az egyénnek intim és gyakori kapcsolata van. Az erős kapcsolatoknak viszonylag kis szerepe van a makrotársadalmi integrációban: nem jellemző, hogy különböző társadalmi csoportokat kötnek össze az egyéni szinten megjelenő erős kapcsolatok. Ezek a kapcsolatok általában homofílek, döntően az egyénhez hasonló társadalmi helyzetben lévő (kor, iskolai végzettség stb.) emberek.

A gyenge kapcsolatok laza szálak, ismeretségek, melyek jelentősége abban áll, hogy hidat képeznek az erős kapcsolatokon keresztül nem elérhető társadalmi helyzetben lévő csoportokhoz, azaz makrotársadalmi szinten integrálják az egyént. Ide soroljuk általában a jelenlegi és volt szomszédokat, tanárokat, munkatársakat, üzleti partnereket, katonatársakat, kollégiumi társakat, felületes személyes ismerősöket, barátok, rokonok által bemutatott egyéb ismerősöket. Az egyéni kapcsolathálózatban megjelenő gyenge kapcsolatok között a sűrűség kicsit, azaz nem jellemző, hogy az egyénhez lazán kötődő személyek egymást is ismerik. Az erős kapcsolatokban bővelkedő egyéni kapcsolathálózat inkább bezárja az egyént. A gyenge kapcsolatokat is tartalmazó network összeköti az egyént a világgal, nyit a makrotársadalom felé (Granovetter 1973, 1974, Gyarmati 2009, Huszti 2015).

Lin (2008) a társadalmi kötődés három formáját különbözteti meg a társas kapcsolatok intenzitása és kölcsönössége szerint:

1. „binding” - az egyénhez legközelebb álló kapcsolatok, melyek több szempontból is (nem, kor, iskolai végzettség stb.) inkább homogén jellegűek. Érzelmeken, kölcsönös segítségnyújtáson alapuló intim és bizalmas kapcsolatok (szülő, gyermek, házastárs, élettárs, bizalmas barát, akikkel az egyén rendszeres és intenzív kapcsolatban áll). 


\section{TEMATIKUS TANULMÁNYOK - Községekben élő immobil fiatalok}

2. „bonding” - az ide tartozók közösen birtokolják az erőforrásokat és az információkat, viszonylag zárt és ugyancsak homogén csoport. Itt már az úgynevezett gyenge kötések is megjelenhetnek.

3. „bridging” - ide a gyenge, különböző társadalmi csoportokon átívelő híd-szerü kapcsolatok sorolhatóak. A gyenge kapcsolatok olyan laza ismertségek, melyek mintegy hidat képezve kapcsolják össze az egyéneket tőlük távolabb lévőkkel, akiket az erős kapcsolataik révén egyébként nem tudnának elérni. A társadalmi integráció szempontjából ezek a legfontosabb kapcsolatok. Ide sorolhatók például a szomszédok, ismerősök (Lin 2008, Dávid - Huszti - Vajda 2015).

A kapcsolathálózat összetételéből következik, hogy milyen típusú, minőségű erőforrásokhoz juthat általuk az egyén. Egy nagyobb méretű kapcsolathálózat több erőforrást, nagyobb mennyiségű információt, többfajta speciális ismeretet nyújt (Albert - Dávid 2007), a kapcsolathálózat heterogenitása, ami általában a gyenge kötések nagyobb számával válik sokszínűbbé, változatos információhoz, különbözőbb ismeretekhez, erőforrásokhoz juttathat (Granovetter 1973, 1974). A kapcsolatok minősége pedig általában az erős kötések által valósul meg.

\section{A társas kapcsolatok jellegzetességei Magyarországon}

Már a rendszerváltás előtt végzett hazai és nemzetközi kutatások is azt mutatták, hogy a nyugati országokhoz képest hazánkban a személyes, támogató hálózatokon belül jóval magasabb a családi, rokoni kapcsolatok aránya, mint máshol. Fontos jellemző a barátválasztás terepe: nemzetközi összehasonlítás szerint a magyarok előszeretettel választják barátaikat a munkatársaik közül. A munkahelyi barátságok továbbra is nagyon fontosak, de egyre jelentősebbek a tanulmányok során, az iskolaévek alatt kialakuló „iskolai” barátságok is (Albert - Dávid 2015). Magyarországon magas azok aránya is, akik nem rendelkeznek egyetlen baráttal sem (Utasi 1990, 1991, Albert - Dávid 2015).

A legfrissebb hazai kutatások szerint felértékelődnek a baráti kapcsolatok (Albert - Dávid 2012, Kopasz et al. 2008). Egyre elfogadottabbá válik, hogy a családtagok mellett/helyett egyéb, nem rokoni kapcsolatok is fontos, bizalmas szerepet töltenek be. Ha a jól működő családi kapcsolatok mellé, azt kiegészítve épülnek be újabb, nem rokoni kapcsolatok a bizalmas hálóba, az mindenképpen egy táguló, bővülő kapcsolatrendszerbeli változást mutat. Hazánkban inkább az figyelhető meg, hogy a nem rokoni, bizalmas kapcsolatok nem a családi kapcsolatok mellé, hanem azok helyett lépnek be, mintegy pótolva az ott meg nem kapott bensőséges viszonyt (Albert - Dávid 2015). 


\section{TEMATIKUS TANULMÁNYOK - Községekben élő immobil fiatalok}

A gyenge kapcsolatokkal foglalkozva, 2006-ban az Angelusz-Tardos szerzőpáros mutatott rá a tényre, hogy a rendszerváltás óta felerősödtek a kapcsolathálózati javak elosztásában, elérésében mutatkozó társadalmi különbségek. Ebből a szempontból meghatározó az egyén származási pozíciója, foglalkozása és egyre erősödő az életkor szerepe: minél idősebb valaki, annál erőteljesebb a kapcsolati erőforrások csökkenése. További szakadékot mutattak ki kapcsolathálózati szempontból a munkaerő piaci aktivitás tekintetében az aktívak és inaktívak között (Angelusz - Tardos 2006).

Megerősítve a fent írtakat, a legutóbbi vonatkozó kutatások szerint a magyar társadalomban kapcsolathálózati szempontból a legjelentősebb szegmentáló dimenziók a munkaerőpiaci státusz, a nem és az életkor (Kopasz et al. 2008, Albert - Dávid 2015).

A rendszerváltást követő társadalmi folyamatok nyomán az egyéni kapcsolathálózatok még inkább bezáródtak: az addig is nagyon kisszámú kevés szomszédsági, munkahelyi kapcsolatok még inkább háttérbe szorultak, és az egyes társadalmi rétegek egyre inkább saját határaik közé kényszerültek, egyfajta „osztályspecifikus bezáródás" volt megfigyelhető (Angelusz - Tardos 1998, Utasi 2002a, 2002b, Albert Dávid 2003).

Az eddigi hazai vizsgálatok általános tapasztalata, hogy az életkor, az iskolai végzettség, munkaerőpiaci és jövedelmi helyzet által meghatározott társadalmi státusz erős összefüggést mutat mind a kapcsolathálózat méretével, mind összetételével. Az életkor növekedése, a gazdasági inaktivitás, az alacsony iskolázottság korlátozza a kapcsolati javak elérhetőségét (Albert - Dávid 1998, 2003, 2015, Gerő - Hajdú 2015). A nem szerinti eltérések a kapcsolathálózat mérete és összetétele szempontjából az ezredforduló után elhalványultak, amelyet a nők erőteljesebb munkaerőpiaci részvételével magyaráznak a kutatások (Angelusz - Tardos 2006).

A település nagysága és a fizikai távolság befolyásolja a közeli és távolabbi családtagokkal való kapcsolattartás intenzitását. Általában megállapítható, hogy a kisebb településeken jobban jellemző a családtagok közötti kapcsolatok intenzitása (Utasi 2013).

A társadalmi integrációval összefüggő legfrissebb kutatások kapcsolathálózati adatai azt mutatják, hogy a hazai felnőtt népesség 42\%-ának szűkös egyéni kapcsolatrendszere van, így hátrányosnak tekinthető a személyközi integráltság szempontjából (Albert - Dávid - Gerő - Hajdu 2017).

A 18-29 éves korosztály egyéni kapcsolathálózatának néhány szegmensét vizsgálva, a legfrissebb vonatkozó kutatások alapján megállapítható, hogy a fiatalok bizalmas kapcsolathálózat mérete átlag feletti $(2,6$ vs. 2,2) és a bizalmas kapcsolatok száma lineárisan csökken az életkor előrehaladásával. A barátok száma is a 18-29 évesek körében a legmagasabb $(4,9)$ és az életkor növekedésével folyamatosan csökkenő tendenciát mutat. A mozgósítható gyenge kötések száma azonban a fia- 


\section{TEMATIKUS TANULMÁNYOK - Községekben élő immobil fiatalok}

talok körében átlag alatti $(5,03$ vs. 5,4), viszont kapcsolataik a legmagasabb presztízsűek. A kisebb településeken több gyenge kapcsolatot tudnak mozgósítani az emberek, viszont ezek zöme alacsonyabb presztízsủ (Albert - Dávid 2015).

Kapcsolati naplós adatok alapján megállapítottuk, hogy a kapcsolathálózat mérete és az egyéni interakciók száma összefügg a településtípussal: a falvakban élők rendelkeztek a legtöbb ismerőssel $(8,3)$, a fővárosban élők a legkevesebbel $(6,6)$. A legtöbb beszélgetést $(12,2)$ is a falusiak folytatták a vizsgált periódusban (2 nap), a legkevesebbet $(8,9)$ pedig a megyei jogú városokban élők. A falvakban élők kapcsolathálózatának 51\%-át alkotják a rokoni kapcsolatok, mely lényegesen magasabb, mint a megyei jogú városokban (41\%) vagy a fơvárosban (45\%) élők esetén (Dávid Lukács - Huszti - Barna 2017).

Az integrációs kutatás eredményeiből érdemes kiemelni azt is, hogy a településtípus hatása, függetlenül az egyén társadalmi pozíciójától, szignifikáns és a nagyobb településen élőknek több erős kötése van. Relatíve legtöbb erős kapcsolattal a Kelet-Magyarországon és Közép-Magyarországon rendelkeznek az emberek. A gyenge kötésekkel kapcsolatban ezzel ellentétes hatást mutattak ki a szerzők: minél kisebb településen él az egyén, annál több gyenge kapcsolattal bír. Régiókat vizsgálva a Kelet-Magyarországon élők magas gyenge kötéseinek a számát lehet kiemelni. A téma szempontjából további fontos megállapítás, hogy a kisebb településeken élők közül azoknak van több gyenge kapcsolata, akiknek a környékén nem élnek szegények. A kisebb településeken a szegregált környék elvágja az egyént a gyenge kapcsolatoktól (Koltai - Nemes 2017).

\section{Módszer, minta}

A tanulmány alapját az MTA Kiválósági Együttműködési Programja Mobilitás Kutatási Centrum programja keretében végzett kutatás adja. A kutatás 2500 fó alatti településen élő, 19-25 év között falusi fiatalok körében zajlott strukturált interjúk készítésével. Az interjúalanyok kiválasztása nem valószínűségi mintavétellel történt. Olyan fiatalok kerülhettek a mintába, akik: 1) befejezték tanulmányaikat, 2) a falujukban maradtak, 3) a szüleik is ugyanabban a faluban élnek. A kutatás keretében összesen 104 interjú készült 53 fiatal és 51 szülő részvételével. Az interjúkat 2018 nyarán-őszén rögzítették a Debreceni Egyetem hallgatói saját falujukban. A megkérdezettek átlagéletkora 22,7 (min. 18, max. 24). A megkérdezett fiatalok az ország északi és keleti régióiban, 5 megye 15 településén élnek. A települések szinte mindegyike komplex programmal fejlesztendő járásokban van.

$\mathrm{Az}$ interjú több kérdésblokk mentén vizsgálta a fiatalok immobilitásának okait. Ennek során az egyéni kapcsolatokkal több kérdés, illetve egy konkrét kérdésblokk is foglalkozott. Ezek közül jelen elemzés során a következő témakörök és interjúkérések kerülnek részletes bemutatásra: 


\section{TEMATIKUS TANULMÁNYOK - Községekben élő immobil fiatalok}

1. Erős és gyenge kapcsolatok az egyéni networkben, a kapcsolattartás gyakorisága, célja, módja, fontossága

- Jelenlegi család összetétele („Kérem, mutassa be a saját családját, akikkel jelenleg egy háztartásban él!")

- Kapcsolattartás a faluban maradtak családtagokkal („Mennyire tartják a kapcsolatot a faluban maradt családtagokkal, milyen szorosak ezek a kapcsolatok?")

- Kapcsolattartás az elköltözött családtagokkal („Mennyire tartják a kapcsolatot az elköltözött családtagokkal, milyen gyakran találkoznak?")

- Baráti, rokoni, ismerősi kapcsolatok a faluban („Vannak-e a faluban baráti, rokoni, ismerősi kapcsolatai? Ha igen, mutassa be az Ön számára legfontosabbakat! Kikkel tart kapcsolatot és milyen gyakran, milyen ügyekben?”)

- A kapcsolattartás formája a faluban élő ismerősökkel, rokonokkal („Hogyan tartja a kapcsolatot a faluban élő ismerősökkel, rokonokkal?")

- A találkozások gyakorisága, célja a faluban élőkkel („Milyen formában, milyen gyakran szoktak találkozni, együtt lenni, szórakozni a faluban élő ismerősökkel? Mit jelent a szórakozás a találkozások alkalmával?”)

- Falun kívüli fontos kapcsolatok („Vannak-e a falun kívüli fontos kapcsolatai? Ha vannak, mutassa be azokat [nem helyben élő rokonok, barátok, ismerősök].")

- Kapcsolattartás a falun kívüli kapcsolatokkal („Hogyan tartja velük a kapcsolatot? Mennyire van jelen az internetes/online kapcsolattartás a mindennapokban?")

- A kapcsolatok fontossága („Hogyan ítéli meg, a faluban vagy a falun kívüliek meghatározóbbak, vagy melyik miért fontos az Ön számára?")

\section{A kapcsolatok funkciói, reciprok kapcsolatok az egyéni networkben}

- Fontos dolgok intézése a falusiaknak („A munkahelyed és a munkatársaid révén el tudsz-e intézni fontos dolgokat a falusiaknak? (szerelés, javítás, építkezés, szállítás, mezőgazdasági munkák stb.”)

- Fontos szerep a faluban („Fontos ember vagy-e a falusi mulatásban, buliban? És a falusi életben?")

- Tartós viszonosság („Vannak-e olyan rokonaid, barátaid, akikkel tartósan valamilyen viszonosságban vagytok? Akiknek gyakrabban szoktál segíteni ebben-abban, de akikre te is bármikor számíthatsz.” Illetve „Mennyire érzed úgy, hogy itt te is számíthatsz másokra?")

Az interjúkból származó információk arra ugyan nem alkalmasak, hogy pontosan és részleteiben feltárjuk a fiatalok egocentrikus kapcsolathálózatának kiterjedtségét és összetételét, de arra igen, hogy azt megvizsgáljuk, hogy a fiatalokat körülvevő szo- 


\section{TEMATIKUS TANULMÁNYOK - Községekben élő immobil fiatalok}

lidaritásháló szövetei hogyan járulnak hozzá az otthonmaradás mellett döntéshez, de legalábbis az otthonmaradás indokai között milyen narratívában jelennek meg a társas kapcsolatok. Annak ismeretében, hogy a fiatal felnőttből önálló felnőtté válás folyamata mennyire összetett, most azt vizsgáljuk, hogy a családon belüli és kívüli kapcsolatok, helyben fellelhető viszonosságok, reciprok kapcsolatok mennyiben lépnek a felnőtté válás feltételeinek megteremtésében elsődlegessé a falusi fiatalok esetében és ezáltal mennyire szolgálják az immobilitást.

\section{Eredmények}

A falusi fiatalokkal készített interjúk alapján feltárt kapcsolathálózat részletezésére egy koncentrikus kör mentén kerül sor: a kör közepén a vizsgált személy áll, majd az őt körülvevő legközelebbi kapcsolatok a közeli családtagok, majd a távolabbi családtagok, rokonok. Őket követik a közeli barátok, a baráti társaságok, majd a munkatársak, szomszédság, az utcabeliek és a falubeli ismerősök.

\section{CSALÁDI KAPCSOLATOK}

A vizsgált fiatalok általában többgyermekes családokban nőttek fel. A megkérdezett fiatalok szüleinek átlagosan 2,8 gyermeke volt (min. 1, max. 11, Mod. 2).

A kibocsájtó család méretét az interjúk alapján a jelenleg egy háztartásban élők számával lehet leírni. Ezek alapján megállapítható, hogy a megkérdezett fiatalok jellemzően négytagú háztartásokban élnek, ahol általában a szülők a megkérdezett és a testvére él egy fedél alatt.

Viszonylag magas a nagyobb - a megkérdezettel együtt legalább hatan együtt élő - háztartások aránya is a mintában. Ezekben a háztartásokban jellemzően a gyermekek száma magas, de néhány helyen előfordul a nagyszülőkkel való együttélés is.

1. táblázat. A háztartás nagysága

\begin{tabular}{|l|c|c|}
\hline A fiatallal együtt... & N & $\%$ \\
\hline kéttagú háztartás & 3 & 6 \\
\hline háromtagú háztartás & 10 & 19 \\
\hline négytagú háztartás & 16 & 17 \\
\hline öttagú háztartás & 9 & 27 \\
\hline hat és többtagú háztartás & 14 & 100 \\
\hline Összesen & $52^{*}$ & 31 \\
\hline
\end{tabular}

*N=egy válaszadó esetén nincs vonatkozó adat Forrás: Saját szerkesztés 


\section{TEMATIKUS TANULMÁNYOK - Községekben élő immobil fiatalok}

A kutatás során megkérdezett fiatalok fele hajadon vagy nőtlen volt a kérdezés idején, 20 fő (ebből 15 lány/nő) élt élettársi vagy párkapcsolatban. A házasok aránya alacsony volt, mindössze hat fő volt házas a vizsgálat idején, és egy válaszadó volt elvált családi állapota szerint.

Azok a fiatalok, akik házasságban éltek a megkérdezés idején ( 6 fő) egyrészt saját családban ( 3 fó), másrészt kiterjesztett családban ( 3 fó) éltek. Az élettársi vagy párkapcsolatban élő fiatalok jelentős része (20-ból 14-en) élt még a szülőkkel együtt, egy háztartásban. Csupán ketten voltak, akik saját családban éltek élettársi vagy párkapcsolatban. Négy fiatal kiterjesztett családokban él együtt párjaikkal.

A megkérdezett fiatalok közül kilencnek volt gyermeke. A gyermekek száma legygyakrabban egy volt, illetve néhány kétgyermekes fiatal és egy négygyermekes férfi került a vizsgált fiatalok közé.

2. táblázat. A megkérdezett családi állapota

\begin{tabular}{|l|c|c|}
\hline & $\mathbf{N}$ & $\mathbf{\%}$ \\
\hline Hajadon/nőtlen & 26 & 50 \\
\hline Házas & 6 & 11 \\
\hline Élettársi vagy párkapcsolatban él & 20 & 37 \\
\hline Elvált & 1 & 2 \\
\hline Összesen & $\mathbf{5 3}$ & $\mathbf{1 0 0}$ \\
\hline
\end{tabular}

Forrás: Saját szerkesztés

\section{Kapcsolattartás a családtagokkal, rokonokkal}

A legközelebbi családtagokkal, közeli és távolabbi rokonokkal való kapcsolatokra vonatkozóan az interjú során azt kérdezték a fiataloktól, hogy vannak-e a faluban rokonaik, és ha vannak, akkor milyen gyakran tartják velük a kapcsolatot és milyen szoros ez a kapcsolat? Továbbá kérdések voltak arra vonatkozóan is, hogy vannak- e a fiataloknak olyan rokonaik, akik már elköltöztek a faluból, vagy nem is éltek itt és velük milyen gyakran tartják a kapcsolatot.

A faluban lévő szűkebb és tágabb rokonság a mikroszolidaritást jelentheti, aktív, fizikailag a közelben lévő, akár multifunkcionális kapcsolatokat. A szívességi háló, az elnyújtott reciprocitás része lehet, melyen különböző erőforrások juthatnak el a fiatalokhoz. A falun kívüli rokonok és a velük való kapcsolattartás a falunk kívüli világhoz való kapcsolódást jelentheti és a személyes network heterogenitását növelheti, ezen keresztül az elérhető erőforrásokat szélesítheti.

Az interjúk alapján a megkérdezett fiataloknál a közös fedél, egy háztartásban való együttélés miatt a közvetlen családtagokkal általánosságban a napi kapcsolat 


\section{TEMATIKUS TANULMÁNYOK - Községekben élő immobil fiatalok}

jellemző. A faluban élő egyéb családtagok közül a szülői házat már lehagyó, de a faluban maradt testvérekkel való kapcsolattartás gyakori. A helyben élő más családtagokkal is a mindennapos, de legalább a heti kapcsolattartás jellemző. Azok a fiatalok, akik még eljárnak a településről iskolába, ritkábban találkoznak a helyi rokonokkal az iskolai időszakok alatt. A nyári szünidő általában megélénkíti a rokonokkal való kapcsolattartás gyakoriságát. A faluban élő családtagokkal való kapcsolattartás gyakori formája még a legalább az ünnepek (karácsony, húsvét, születésnap, névnap) alatti találkozások, évente néhány alkalommal.

A szűkebb családtagokkal való gyakori kapcsolattartás sokkal jellemzőbb, mint a távolabbi rokonokkal tartott intenzív kapcsolat. Korábbi kutatások igazolják, hogy „míg a szúk családi közösség összezár, addig a családi közösségen kívül eső rokoni körrel tartott kapcsolat meglehetősen laza, a távolabbi rokonok az erős kapcsolatok hálójának peremén helyezkednek el." (Utasi 2013: 41)

Ezzel összhangban, a kutatás során megkérdezett minden ötödik fiatalra $(\mathrm{n}=10$, $19 \%$ ) jellemző az, hogy a faluban élő távolabbi rokonaikkal szinte egyáltalán nem tartják a kapcsolatot. Ennek oka az elmondottak alapján az időhiány, az érdektelenség, illetve személyes, családi konfliktusok lehetnek.

A faluban maradt családtagokkal hogyan tartják a kapcsolatot?

„Csak köszönés alapon. Szia-szia, mi újság? Az alapvető dolgokat megbeszéljük, hogy milyen az időjárás, de nincs kapcsolat." (25 éves nó)

„Semennyire. Csak az ilyen, hát annyira, hogy néha szoktunk szóba állni, köszönni, de azt sem minddel. Ennyi." (23 éves nö)

„Mindenkinek megvan a kis élete.” (25 éves nő)

„Hát, annyira nem. A keresztapám mondjuk, az itt van. Csak hát ez is egy régi családi vita miatt nem tartjuk úgymond a kapcsolatot." (21 éves férfi)

„Hát úgy igazából csak távoli rokonok vannak a faluban, akikkel nem tartjuk a kapcsolatot, tehát úgy köszönünk az úton és körülbelül ennyibe megállt a rokonság." (24 éves nó).

A megkérdezett fiatalok elmondásai alapján a rokoni kapcsolatok hiányát a barátok veszik át. Azoknál a fiataloknál (6 fő), akik azt mondták, hogy nincsenek rokoni kapcsolataik a faluban (vagy vannak, de mivel nem tartják a kapcsolatot, olyan, mintha nem is lennének), a kiemelt reciprok kapcsolatot minden esetben a barátok jelentették. 


\section{TEMATIKUS TANULMÁNYOK - Községekben élő immobil fiatalok}

A megkérdezett fiatalok jelentős részének nem volt olyan családtagja, aki elköltözött a faluból. Akiknek van ilyen családtagjuk, azok egy része (5 fő) napi szintű kapcsolattartásról számolt be. Ezek a kapcsolatok jellemzően a testvérek. Illetve itt is az évente egy-két ünnepi alkalomhoz kötött találkozások gyakoribbak. Jellemző, hogy a nem faluban élő családtagokkal, rokonokkal való kapcsolattartás egyirányú: az elköltözöttek látogatnak haza és nem az ottmaradottak mozdulnak ki. Ennek nyilvánvaló indoka lehet a nagyobb rokonsággal való találkozás megoldása az elköltözötteknek.

\section{Baráti kapcsolatok a faluban}

Mivel az interjú során nem volt a barátok pontos számára vonatkozó kérdés, a baráti kapcsolatokat a „Vannak-e a faluban baráti, rokoni, ismerősi kapcsolatai?” kérdésre adott válaszokból ismerhetjük meg. Ezek alapján elmondható, hogy a vizsgált falusi fiatalok jelentős részének van baráti kapcsolata, még inkább baráti társasága a faluban. A faluban élő barátok sok esetben a régi általános iskolai osztálytársakból verbuválódnak és fontos szerepet töltenek be a megkérdezett fiatalok életében. A jelenség jellemzőbb a megkérdezett fiatal férfiakra.

„Azokkal a barátaimmal, akikkel így nagyon tartom a kapcsolatot, igazából óvodás korunk óta tart, ami hát elég sok. Azóta viszont folyamatosan tartjuk a kapcsolatot. Ugyebár egy csoportba jártunk, egy osztályba jártunk 8 éven keresztül..." (20 éves férfi)

„Barátok? Ők is falubeliek, együtt nőttünk fel.” (22 éves férfi)

„Hát ugye, az általános iskolából pár emberrel tartom a kapcsolatot.” (25 éves férfi)

„Hát rengeteg barátomat a suliból ismerek még... általános iskolából maradtam meg barátaim. Úgy ennyi. (18 éves férfi)

„Hát, részben osztálytársak, mert itt jártam általános iskolába. Azokkal tartom..." (21 éves férfi)

„Ide jártunk oviba, ide jártunk iskolába és akikkel elkezdtük az ovit és a nyolcadikat befejeztük. Nem is baráti kapcsolat ez azt mondanám, .... hanem ez ilyen féltestvéri viszony és nekem ezek vannak itt meg." (24 éves nö) 


\section{TEMATIKUS TANULMÁNYOK - Községekben élő immobil fiatalok}

„Barátaim vannak a faluban, ôk olyan barátok, akikkel már általános iskolában ismertem meg őket, és még most is tartjuk a kapcsolatot." (22 éves nó)

Hat fiatal mondta azt egyértelmúen, hogy neki nincsenek a faluban baráti kapcsolatai. Az ő esetükben megfigyelhető, hogy a falun kívüli kapcsolatok erősebben vannak jelen a személyes networkben. Ezek a kapcsolatok jellemzően baráti és rokoni kapcsolatok. Közülük háromra jellemző az, hogy el szeretnének költözni, esetükben mondhatjuk azt talán, hogy a falun kívüli kapcsolatok növelik a mobilitási szándékot.

A helyi barátokkal való kapcsolattartás, szórakozás gyakran valamelyik háznál való, étkezéssel összekötött összejövetel formájában valósul meg. Nyári időszakban legjellemzőbb a közös szalonnasütés, bográcsolás, „sütögetés”, „nyársalás”, „piknik”, de gyakori a kocsmázás, bulizás is, ami az elmondások alapján gyakran kötődik öszsze „iszogatással”.

Kiemelt fontosságú az interjúk során említett „beszélgetés”, mint a szórakozás egy fajtája. Az értékelhető válaszokból 17 esetben jelölték meg a beszélgetést egyértelműen az összejövetel céljának. Megfigyelhető, hogy a beszélgetés, mint az összejövetel célja szinte egyformán fordul elő mind a nők, mind a férfiak elmondásaiban.

3. táblázat. A baráti összejárások formái nemenként

\begin{tabular}{|c|c|c|c|}
\hline \multirow[t]{2}{*}{ Az összejárás formája } & \multicolumn{2}{|c|}{ Említések száma } & \multirow{2}{*}{ Összesen } \\
\hline & Férfi & Nő & \\
\hline Beszélgetés & 8 & 9 & 17 \\
\hline $\begin{array}{l}\text { Szalonnasütés, bográcsolás, sütögetés, nyársalás, } \\
\text { piknik, grillezés }\end{array}$ & 6 & 10 & 16 \\
\hline Pizzázó, bowling, biliárd, lottózó, mozi, vásárlás & 4 & 7 & 11 \\
\hline Kocsmázás, iszogatás, sörözés, presszó & 5 & 4 & 9 \\
\hline Diszkó, bulizás & 7 & 2 & 9 \\
\hline Kártya, foci, horgászat, strand, meccsnézés & 8 & 0 & 8 \\
\hline Séta, futás, biciklizés & 1 & 5 & 6 \\
\hline $\begin{array}{l}\text { Házibuli, otthoni filmnézés a barátokkal, darts, Xbox } \\
\text { otthon }\end{array}$ & 3 & 3 & 6 \\
\hline Kávézás & 0 & 3 & 3 \\
\hline
\end{tabular}

Forrás: Saját szerkesztés

Bizonyos összejöveteli célok inkább a lányokra, nőkre jellemző, míg mások inkább a fiúkra, férfiakra. Így például a kávézás, moziba, vásárolni járás, pizzázóba 


\section{TEMATIKUS TANULMÁNYOK - Községekben élő immobil fiatalok}

beülés, illetve a faluban végezhető sporttevékenységek, mint a futás, biciklizés, séta inkább a nőkre jellemző. A megkérdezett fiatal férfiak összejöveteleit a bulizás, kártyázás, focizás, közös meccsnézés, horgászat, strandra járás dominálja. Nincs nemi különbség a kocsmázni, sörözni, iszogatni járás esetén és az otthoni összejövetelek, házibulik, filmnézés említésénél.

\section{Falusi fontos kapcsolatok}

Ahogyan azt már fentebb is láttuk, az interjú során a lokális kapcsolatokra vonatkozó kérdés így hangzott: „Vannak-e a faluban baráti, rokoni, ismerősi kapcsolatai? Ha igen, mutassa be az Ön számára a legfontosabbakat!” A kérdésre adott egyértelműen besorolható válaszok alapján megállapítható, hogy a fontos kapcsolatokra vonatkozóan a fiatalok narratívájában elsőként a baráti kapcsolatok említése jelenik meg, ami életkori sajátosságoknak is betudható jellegzetesség. A későbbiek folyamán látni fogjuk, hogy éppen ezek a kapcsolatok azok, melyek a különböző erőforrások áramoltatásában nagy szerepet játszanak, részt vesznek a mindennapi szolgáltatás cserében. Ezek jelenti a kiszámíthatóságot, azt a mikrotársadalmi szolidaritást, amelyre minden esetben számítani lehet.

4. táblázat. A fontos kapcsolatok típusa

\begin{tabular}{|l|c|}
\hline \multicolumn{1}{|c|}{ A kapcsolat típusa } & Említések száma \\
\hline $\begin{array}{l}\text { Család, rokonok } \\
\text { (unokatestvér, nagyszülő, keresztanya) }\end{array}$ & 14 \\
\hline Barátok & 20 \\
\hline Szomszédok & 2 \\
\hline
\end{tabular}

Forrás: Saját szerkesztés

\section{A falun kívüli kapcsolatok típusa}

Az interjú során megkérdezték a fiataloktól azt is, hogy vannak-e a falun kívül kapcsolataik. A kérdés így hangzott: „Vannak-e falun kívül fontos kapcsolataik? Ha vannak, mutassa be azokat!"

A fiatalok által elmondottak alapján megállapítható, hogy a falun kívüli kapcsolatok alapvetően barátok, illetve korábbi vagy jelenlegi osztálytársak, csoporttársak. A falun kívüli barátságok maguk is többnyire a volt osztálytársakból, iskolatársakból alakulnak ki. Jellemző még a faluból elköltözött közeli és távolabbi rokonokkal való szorosabb kapcsolattartás is. Ezen kívül a munkahelyi vagy szabadidős elfoglaltság- 


\section{TEMATIKUS TANULMÁNYOK - Községekben élő immobil fiatalok}

hoz kapcsolható ismerősök, csapattársak, lazább barátságok jelennek meg a fontos kapcsolatok említése során.

5. táblázat. Falun kívüli fontos kapcsolatok

\begin{tabular}{|l|c|}
\hline \multicolumn{1}{|c|}{ A kapcsolat típusa } & Említések száma \\
\hline Közeli rokon (testvér, szülő), vőlegény & 3 \\
\hline Távolabbi rokonok & 12 \\
\hline Barát & 18 \\
\hline Iskolatársak (jelenlegi, korábbi) & 2 \\
\hline Laza ismeretségek, haverok & 4 \\
\hline $\begin{array}{l}\text { Egyéb: munkahelyi ismerős, ismerős, csapattárs, } \\
\text { gyülekezeti társ }\end{array}$ & 18 \\
\hline
\end{tabular}

Forrás: Saját szerkesztés

A falun kívüli kapcsolattartás módjára is rákérdeztek az interjú során: „Hogyan tartja velük a kapcsolatot? Mennyire van jelen az internetes/online kapcsolattartás a mindennapokban?"

A kérdésre adott értékelhető válaszok alapján látható, hogy a falun kívüli fontos kapcsolatokkal a fiatalok leggyakrabban személyesen és interneten, jellemzően valamilyen online üzenetküldő felület segítségével tartják a kapcsolatot, ami egyébként az elmondások alapján meglehetősen gyakori kapcsolattartást eredményez. A kétféle kapcsolattartási mód megerősítheti azt, hogy ezek a kapcsolatok valóban fontos és erős kapcsolatok lehetnek a fiatalok életében, hiszen nem csak Internet segítségével, hanem személyesen is tartják a kapcsolatot.

6. táblázat. A falun kívüli fontos kapcsolatokkal való kapcsolattartás módja

\begin{tabular}{|l|c|}
\hline \multicolumn{1}{|c|}{ A kapcsolattartás módja } & Említések száma \\
\hline Személyesen & 4 \\
\hline Telefonon & 3 \\
\hline Interneten/online & 4 \\
\hline Személyesen és interneten/online & 17 \\
\hline Személyesen és telefonon & 3 \\
\hline Telefonon és interneten/online & 3 \\
\hline Személyesen, telefonon, interneten/online & 5 \\
\hline
\end{tabular}

Forrás: Saját szerkesztés 


\section{TEMATIKUS TANULMÁNYOK - Községekben élő immobil fiatalok}

\section{Falusi kontra falun kívüli kapcsolatok}

Az interjúk lehetőséget adnak arra, hogy az elmondottak alapján megvizsgáljuk, vajon azok a fiatalok, akiknek van a falun kívül fontos kapcsolata, jobban vágyónak-e el a faluból, jellemzőbb-e körükben a mobilitási szándék?

A kérdést vizsgálva az interjús narratívák a helyi kapcsolatok visszahúzó erejét mutatják: még azokra a fiatalokra sem jellemző, hogy szeretnének elköltözni, akiknek van a falun kívül fontos kapcsolata. A falun kívüli kapcsolatoknak úgy túnik nincs motiváló ereje a mobilitási szándékot illetően.

7. táblázat. Kapcsolatok és mobilitás

\begin{tabular}{|l|c|c|}
\hline \multicolumn{1}{|c|}{ Típusok } & N & \% \\
\hline Van a falun kívül kapcsolata, és van mobilitási szándéka & 17 & 35 \\
\hline $\begin{array}{l}\text { Van a falun kívüli kapcsolata, de nincs mobilitási szán- } \\
\text { déka }\end{array}$ & 26 & 53 \\
\hline $\begin{array}{l}\text { Nincs falun kívüli kapcsolata, de van mobilitási szándé- } \\
\text { ka }\end{array}$ & 2 & 4 \\
\hline $\begin{array}{l}\text { Nincs falun kívüli kapcsolata és nincs mobilitási szándé- } \\
\text { ka sem. }\end{array}$ & 4 & 8 \\
\hline Összesen & 49 & 100 \\
\hline
\end{tabular}

Forrás: Saját szerkesztés

Arra a kérdésre, hogy vajon a falusi vagy a nem falusi kapcsolatok a fontosabbak a megkérdezetteknek 39 értékelhető válasz született. Ezek alapján a fentebb leírtakat lehet alátámasztani: legtöbben $(41 \%, \mathrm{n}=16)$ ugyanis azt mondták, hogy nekik a faluban élő kapcsolatok fontosabbak, de sokaknak $(36 \%, n=14)$ mindkét típusú kapcsolat fontos volt, nem tudott különbséget tenni. Kilenc válaszadó (23\%) mondta azt, hogy neki a falun kívüli kapcsolatok a fontosabbak.

\section{Munkatársak, szomszédok, ismerősök a kapcsolathálózatban}

A gyenge kapcsolatok közül az interjúk során említésre kerülő munkahelyi, szomszédsági kapcsolatokat és a falusi ismerősöket tudjuk vizsgálni. Ebbe a sorba kívánkozna tulajdonképpen a volt osztálytársakkal, iskolatársakkal való kapcsolattartás vizsgálata is. Mivel az interjúzott fiatalok esetén azonban ezekből a kapcsolatokból lettek a barátok, ez a kapcsolattípus inkább ott került bemutatásra. 


\section{Munkatársak a networkben}

A megkérdezett fiatalok közül 42 főnek volt munkahelye, 45\%-uk ( $n=19)$ rendelkezett a kutatás idején falun belüli munkahellyel és nagyobb részüknek $(n=23)$ volt a kérdezés idején falun kívül munkahelye. A faluban dolgozó fiatalok közülük csupán hatan voltak (31\%), akik a kapcsolataikról beszélve említettek munkahelyi kapcsolatokat is és közülük négyen egy adott településen élnek. Akiknek a falun kívül volt munkahelye, csupán ketten említették meg munkatársaikat az interjú során. Ezek alapján úgy tűnik, hogy sem a falun belüli, sem a falun kívüli munkatársak nem képezik aktív tagját a fiatalok személyes kapcsolathálózatának.

Ez egybecseng Utasi korábbi kutatási eredményével, miszerint a munkatársakkal tartott kapcsolat gyakorisága minden településtípuson messze elmarad az erős kapcsolatokhoz képest (Utasi 2013).

\section{Szomszédok a networkben}

Szomszédsági kapcsolatokat, utcabelieket a megkérdezett fiatalok 22\%-a (n=12) említett az interjúk során. Közülük heten dolgoznak, öten pedig munkanélküliség vagy gyermeknevelés miatt vannak otthon. Az utóbbiak esetén a szomszédokkal való gyakoribb vagy szorosabb kapcsolattartás a gyermeknevelés miatt otthon töltött idővel is magyarázható. A szomszédokkal való kapcsolattartás általánosságban is inkább a nőkre volt jellemző (n=9 vs. 3 ).

\section{Ismerősök a networkben}

Az ismerősi kapcsolatok említésének értelmezése jelen mérés során eltér a megszokottól. Maga az „ismerős” kifejezés jelentése egészen mást foglalhat magában egy olyan településen, ahol „szinte mindenki ismer mindenkit”, „mindenki ismerőse mindenkinek". Sokszor a rokon, vagy az utcabeli, a szomszéd is tulajdonképpen az ismerős kategóriába sorolható, de azok is, akikkel a kisboltban, a piacon vagy csak úgy, a faluban találkoznak a helybeliek. Így félrevezethető lenne bármire is következtetni az interjúban elhangzott kérdésre - miszerint vannak-e a megkérdezettnek baráti, rokoni, ismerősi kapcsolatai a faluban? - adott válaszokból. Itt ugyanis, ha a válaszoló nem is tér ki külön az ismerősi kapcsolatok említésére, a barátok és rokonok említése már eleget tehet egyben az ismerősi kontaktok felsorolásnak is. Az interjús szövegek nem teszik lehetővé a pontosabb vizsgálatot.

Az ismerősi kapcsolatoknak a kivonása, vagy figyelmen kívül hagyása a vizsgált populáció immobilitásában azonban nem lenne praktikus döntés, hiszen a falusi fiatalokat körülvevő „mindennapos ismerősség”, a „mindenki ismer valamilyen szinten mindenkit" érzés adhat egyfajta társadalmi beágyazottság érzetet, egy valahová való 


\section{TEMATIKUS TANULMÁNYOK - Községekben élő immobil fiatalok}

tartozás tudatot, közösségiséget, mely hozzájárulhat ahhoz, hogy a fiatalok (egyelőre) otthon maradtak.

„[D]e ugye van az a közösség, ahová beilleszkedtél és nagyjából mióta az eszedet tudod, benne élsz és máshogy viszonyulnak hozzád az emberek." (25 éves férfi)

„Egész Galgóc olyan picike 370 fös lakossal, hogy mindenki tudja egymás dolgát. Ismerik egymást." (25 éves nő)

„[E]gy kis falu és itt mindenki, lényegében mindenki kapcsolatban van mindenkivel napi szinten boltba, postán, gyógyszertárba, bárhol." (25 éves nó)

„Mivel kis falu, így azt mondom, mindenki ismer mindenkit. Mindenki köszön mindenkinek." (20 éves férfi)

„A falukra az jellemző általában, mint itt is, hogy mindenki ismer mindenkit, mert ugye kis település, az utcán mindig találkozunk, a szomszédok is ismerik egymást." (22 éves nő)

\section{A településen maradás szubjektív okai és a társas kapcsolatok}

„Mert ezt szoktuk meg. Nem akartunk változtatni. Minden kezdet nehéz máshol. Hát megpróbáltam én is elmenni, visszajöttem. Meg volt, amikor a lányom is elment, de ök is visszajöttek. Végül mindenki visszatér szinte. ... Mi lehet az oka ennek, a falu megtartó ereje? (Kérdező) - Nem a falunak, a családnak." (62 éves nö)

Az interjú során a fiatalokat arról is kérdezték, hogy összességében mi indokolja azt, hogy az adott településen maradtak. Az alapvetően szubjektív elemeket tartalmazó és pontosabban értelmezhető, egyértelmű válaszokat aszerint lettek kategorizálva, hogy azokban mennyire jelenik meg az immobilitás szubjektív magyarázata során a család, illetve a faluhoz köthető baráti és rokoni kapcsolatok. 


\section{TEMATIKUS TANULMÁNYOK - Községekben élő immobil fiatalok}

8. táblázat. Az immobilitás okai a fiatalok szerint

\begin{tabular}{|l|c|}
\hline \multicolumn{1}{|c|}{ Az immobilitás szubjektív oka } & Említések száma \\
\hline Család & 27 \\
\hline Rokonság & 2 \\
\hline Partnerkapcsolat & 4 \\
\hline Barátok & 9 \\
\hline Falusi emberek, kapcsolatok, utcabeliek, ismertség & 9 \\
\hline Biztonság, biztos háttér & 3 \\
\hline Szülői támogatás, még aktív tanulmányok & 4 \\
\hline Munkahely & 8 \\
\hline A településhez kötődő pozitív érzelmek & 10 \\
\hline Személyes múlt & 6 \\
\hline Megszokás & 3 \\
\hline Anyagi okok, ház, alacsony ingatlanár, takarékoskodás & 9 \\
\hline Nincs más választás & 4 \\
\hline Ideiglenes, menni akar & 3 \\
\hline $\begin{array}{l}\text { Egyéb (rossz döntés, nincs még saját családja, példát akar } \\
\text { mutatni, hit, fel sem merült a költözés) }\end{array}$ & 4 \\
\hline
\end{tabular}

Forrás: Saját szerkesztés

Az immobilitás szubjektív okai között a fiatalok leggyakrabban emberi kapcsolataikat említik, ezen belül is elsődlegesen a család megtartó erejét. A családi kapcsolatok húzóereje mellett a faluban élő barátok, továbbá a falusi emberek, a falusi kapcsolatok fontosak az immobilitás magyarázatában. A településhez kötődő pozitív érzelmek is hangsúlyosak.

„Hát, hogy is mondjam: most az itt maradás, a barátok egy része ideköt, a családom, és most még így könnyebb, mint a későbbiekben, mint mikor majd el kell mennem." (19 éves fiú)

„Röghöz kötött vagyok a társaság miatt, az emberek miatt, a környék miatt, meg amit itt már megvalósítottam. Ez mind, amiért maradnék." (22 éves férfi).

Az emberi kapcsolatok mellett racionálisabb megfontolások is megjelennek: az anyagi okok említése mint otthontartó tényező gyakorisága is megfigyelhető. Ez egészül ki a helyben talált munkalehetőséggel, mely biztosíthatja a megélhetést, esetleg 


\section{TEMATIKUS TANULMÁNYOK - Községekben élő immobil fiatalok}

takarékoskodásra is lehetőség nyílik. Az anyagi okok esetén a munkabér hiányát, a munkanélküliséget is említik a fiatalok, illetve ezzel összefüggésben azt, hogy nincs pénz elköltözni, nincs pénz például albérlet finanszírozására. Ide tartozik még a helyben meglévő ingatlan is, mely sok esetben a biztos lakhatást jelenti hosszútávon.

Ha az immobilitás szubjektív narratíváját elemezzük, felmerül a korábban már említett önállósodási folyamat, pontosabban az ezt gátló tényezők említése, ha nem is direkt módon, de mégis több aspektusa is fellelhető ezekben a magyarázatokban.

„A másik ok, hogy nyilván még nincs hova menni, nincsen még saját kis kuckó.” (25 éves nö)

„Ugye most tudok még félretenni, gyüjtögetni a későbbiekre. Itthon vagyok a családdal, van családi ház, bőven elférünk, úgyhogy föként azért, ezért gondoltam, hogy maradok." (24 éves nö)

„Anyuék mindenben segítenek. Vanda (másfél éves lánya) miatt. Itt kellett maradni." (25 éves elvált nö)

„Leginkább, hogy nincs stabil munkahelyem, nem tudok még olyan albérletet kivenni, amit tudnék is fizetni. És hogy innen a bejárás még úgy elmegy viszonylag." (21 éves férfi)

„Jó, mert anyámékkal vagyok itt, végül is jó, szeretek velük lakni. Meg ugye nyilván nem tudok elmenni, mert nem tudok lakást, házat venni. Úgyhogy muszáj, hogy itt legyek, úgy annyira nincs választási lehetőség." (23 éves nő)

„Hát, igazából, amit az előbb is említettem, munka, család, pénz. Röviden enynyi." (24 éves férfi)

Az immobilitás indoklására vonatkozó kérdést feltették mind a fiataloknak, mind szüleiknek, így még jobban megragadható a kapcsolatok generációs szerepe az immobilitásban. 


\section{TEMATIKUS TANULMÁNYOK - Községekben élő immobil fiatalok}

9. táblázat. Az immobilitás okai a szülők szerint

\begin{tabular}{|l|c|}
\hline \multicolumn{1}{|c|}{ Az immobilitás szubjektív oka } & Említések száma \\
\hline $\begin{array}{l}\text { Család (saját kibocsátó - itt voltak a szülők vagy jelenlegi - ide } \\
\text { születtek a gyerekek, ide házasodott) }\end{array}$ & 25 \\
\hline Rokonság (házastárs szülei, rokonai) & 4 \\
\hline Barátok & 3 \\
\hline Kapcsolati tőke, emberek, sok ismerős, összetartás, összefogás & 8 \\
\hline Biztonság & 2 \\
\hline Félelem & 3 \\
\hline Munkahely (saját vagy házastárs, jelenlegi vagy korábbi) & 12 \\
\hline A településhez kötődő pozitív érzelmek & 8 \\
\hline Személyes múlt (itt született, ide telepedett le) & 7 \\
\hline Megszokás & 5 \\
\hline Ház (itt volt, itt örökölt, itt épített) & 8 \\
\hline Nincs más választás, itt ragadt & 6 \\
\hline Nem tudja, nem gondolkodott még rajta, fel sem merült soha & 4 \\
\hline
\end{tabular}

Forrás: Saját szerkesztés

A szülők szubjektív immobilitás magyarázatában is domináns a családi kapcsolatokra való hivatkozás, de másképpen, mint a fiatalokéban. A fiatal még abban a helyzetben van, hogy nem tud, nem akar, nincs lehetősége megteremteni az önálló életet akár falun belül vagy azon kívül. Így a család, a mindennapos boldogulás biztosításával odahúzza. A szülőknél a család immobilitást erősítő szerepe másképp jelenik meg: nem ment a szülő, mert a településen éltek a szülők is, akikről gondoskodni kell(ett), a településre születtek a gyerekek, kisgyerekkel nehéz elindulni, és egyébként is jó a gyereknek ez a közeg, ide köti a házasság, a férje/felesége és az ő rokonsága már a településhez kötődik. A szülők esetében a barátságok nem jelennek meg a falu megtartó erői között. Ez összecseng azokkal a korábbi kutatási eredményekkel, miszerint hazánkban a felnőtt népesség baráti kapcsolatainak száma hagyományosan igen alacsony. Felértékelődik a szülők esetén a kapcsolati tőke szerepe a maradásban. Ez vagy a válaszadó szülő vagy a szülő házastársának jó kapcsolatrendszerének említését jelenti.

„Hát igazából ezen még nem is gondolkodtunk el. De szerintem mondjuk a férjem szempontjából, szerintem mondjuk a családja. Jóformán az összes családja itt él Tiszanánán. Nagyon jók a kapcsolataink. Férjemnek is... Ismerettségei... Hát, igazából ezen nem gondolkodtunk." (36 éves nö) 


\section{TEMATIKUS TANULMÁNYOK - Községekben élő immobil fiatalok}

„Nem vágytam sosem városba menni. Ide vágytam férjhez, itt telepedtem le és nem gondolkodtam azon, hogy máshová menjek." (57 éves nő)

„Én szeretem az embereket és szerintem én ezért maradtam itt. Szeretek emberekkel beszélgetni és ez biztos, ez így van. És a férjemnek itt van munkája." (48 éves nö)

„A gyerekek miatt. Semmi másért. Vagyis a szüleim miatt. Meg a férjem miatt maradtam." (52 éves nő)

„Igen, itt építkeztünk, itt teremtettük meg a kis jövőnket, a kis lakásunkat, meg mindent." (43 éves nö)

A megkérdezett fiatalok szüleinek általában nincsenek mobilitási tervei, nem akarnak máshová költözni. A korábbi tervekre vonatkozóan azonban találunk utalásokat, illetve a maradás magyarázatai és az azokban felsejlő kognitív disszonancia is érzékelhetők az interjús szövegekből.

„Nem volt rá lehetőség, és bennünket ez fogott, bár a páromnak T.(település) szeretete, mert ő nagyon nem. Mi, mikor megesküdtünk, Nyíregyházán kaptunk volna lakást és ő nem jött velem. Kaptunk is. És ő nem jött... Nem jött velem és mindig ő volt az, aki rátette az i-re a pontot... Igen. És így itt maradtunk. Végül is maradtunk, mert itt voltak a szüleink, gondoztuk, ápoltuk őket..." (59 éves nö)

„J.-nek a mamája is itt lakott és beteg volt, és itt kellett maradni. Pedig lett volna lehetöség. Pestre is menni, lett is volna munka akkor J.-nek ottan." (43 éves nő)

Az ismeretlentől való félelem, a megszokott dolgokkal való szakítás nehézsége is sokszor magyarázatként jelenik meg mind a fiatal, mind a szülők narratívájában.

„Leginkább a családom miatt, meg tényleg az, hogy nem mernék nekivágni egyedül egy ilyen nagyobb... nagyobb tervnek." (24 éves nö)

„Mert szerintem féltünk az újtól, féltünk belevágni abba, hogy elmenni más városba, utána, ahogy az ember idősödött, úgy volt vele, hogy még nehezebb beleszokni." (58 éves nő) 


\section{TEMATIKUS TANULMÁNYOK - Községekben élő immobil fiatalok}

\section{„[É]s sajnos azt kell mondanom, hogy 48 évesen nem tehetem meg már azt a feleségemmel, hogy elmenjünk... sajnos mi már nem vagyunk abban a korban, hogy vándoroljunk." (48 éves apa)}

Az anyagi lehetőség említése a szülői narratívákban is megjelenik.

„Mert szegény vagyok, nincs rá lehetőségem, azért maradtam itt, szó szerint.” (57 éves anya)

A fiatalok és a szülők immobilitásának szubjektív indokai az interjúkban rögzítettek szerint sok esetben megfeleltethetők egymásnak, érzékelhető az „átörökített magyarázat", az el nem indulás hasonló indoklása.

10. táblázat. „Összességében miért maradt?”

\begin{tabular}{|c|c|}
\hline Szülő & Fiatal \\
\hline $\begin{array}{l}\text { „Ide köt minket minden, a családot. Amit } \\
\text { édesapám itt felépített dolgokat. Tényleg } \\
\text { teljesen mindent, egzisztenciát, kapcsolati } \\
\text { tőké, ilyesmit.” ( } 41 \text { éves férfi) }\end{array}$ & $\begin{array}{l}\text { „Hogy itt nőttem fel, az nagyon ide köt. } \\
\text { Hogy itt dolgozom, hogy itt a családom. } \\
\text { Amúgy meg biztos, hogy nem maradnék itt.” } \\
\text { (21 éves férfi) }\end{array}$ \\
\hline $\begin{array}{l}\text { „A gyerekek miatt. Semmi másért. Vagy- } \\
\text { is a szüleim miatt. Meg a férjem miatt } \\
\text { maradtam S-n (település)”. (52 éves nő) }\end{array}$ & $\begin{array}{l}\text { „Hát ugye, mivel anyáék is itt laktak. Ide } \\
\text { építkeztek. Tehát itt nőttem fel.” ( } 25 \text { éves } \\
\text { nő) }\end{array}$ \\
\hline $\begin{array}{l}\text { „A család marasztalt itt, nem volt lehetőség } \\
\text { rá, hogy elmenjünk még abba' az időbe', hát } \\
\text { most hova mentünk volna?” (47 éves nő) }\end{array}$ & $\begin{array}{l}\text { "Csakis a családom, csakis az. Nem a mun- } \\
\text { kalehetőség, meg a pénz miatt, csakis azért, } \\
\text { mert a családtagjaim idekötnek." ( } 22 \text { éve } \\
\text { nő) }\end{array}$ \\
\hline $\begin{array}{l}\text { „Összetartás, a falu közössége, meg maga a } \\
\text { falu." (57 éves nő) }\end{array}$ & $\begin{array}{l}\text { „Mert itt mindenki kedves és aranyos és } \\
\text { segítőkész. Itt él a családom, barátaim.” ( } 25 \\
\text { éves nő) }\end{array}$ \\
\hline $\begin{array}{l}\text { „Hát, én a családom miatt vagyok itt, meg } \\
\text { hát én szeretek itt lakni, szeretem ezt a } \\
\text { községet, na az az igazság. Nekem jó itt.” (49 } \\
\text { éves nő) }\end{array}$ & $\begin{array}{l}\text { „Hát a családom, ők. Emiatt így. Meg hát } \\
\text { ugye a barátok is. Meg hát azért szeretek itt } \\
\text { lenni. Sok az ismeretség, és akkor így ezért.” } \\
\text { (22 éves nő) }\end{array}$ \\
\hline $\begin{array}{l}\text { „Ezt szoktuk meg. Ez a..., hogy mindenki } \\
\text { ismer mindenkit...” ( } 45 \text { éves nő) }\end{array}$ & $\begin{array}{l}\text { „Ismerünk mindenkit, ideköt mindenki, } \\
\text { család, és ez így jó.” (22 éves férfi) }\end{array}$ \\
\hline $\begin{array}{l}\text { „Ide születtünk, itt van a család, munkahely, } \\
\text { lakás, csendes falu, szeretünk itt lakni. (58 } \\
\text { éves nő) }\end{array}$ & $\begin{array}{l}\text { „Mert ide születtem és ide köt a szívem.” (24 } \\
\text { éves férfi) }\end{array}$ \\
\hline
\end{tabular}




\section{TEMATIKUS TANULMÁNYOK - Községekben élő immobil fiatalok}

\begin{tabular}{|c|c|}
\hline $\begin{array}{l}\text { „Há' mert itt születtünk. Mink szeretünk itt } \\
\text { élni. Itt is akarunk meghalni.” (60 éves nő) }\end{array}$ & $\begin{array}{l}\text { „Hát itt születtünk. Akkor itt van minden } \\
\text { családtagom. Akkor a párom. Így ennyi.” ( } 21 \\
\text { éves nő) }\end{array}$ \\
\hline $\begin{array}{l}\text { „Nem is tudom. Talán a családi összefogás, } \\
\text { összetartás miatt.” (41 éves nő) }\end{array}$ & $\begin{array}{l}\text { „A család miatt. Azt mondanám, hogy a } \\
\text { család miatt maradtam B-n (település), de } \\
\text { elképzelheto”, hogy változni fog idővel.” ( } 20 \\
\text { éves férfi) }\end{array}$ \\
\hline $\begin{array}{l}\text { „Minket eleve az is vitt a nejemmel, mikor } \\
\text { a szüleim ránk íratták a házat. Ez egy ilyen } \\
\text { marasztaló hatás volt, hogy na, ez a miénk... } \\
\text { Ez egy nagyon nagy erő, hogy na, ez a mi- } \\
\text { énk, senki másé. Itt nőttek fel a gyerekek. Ez } \\
\text { egy nagyon nagy ragaszkodási pont nekem.” } \\
\text { (47 éves férfi) }\end{array}$ & $\begin{array}{l}\text { „Akármilyen csöves is ez a hely, nem tud- } \\
\text { nám itt hagyni. Már lehet az maga, érted, } \\
\text { hogy a megszokás. Az, hogy ebbe nőttem fel. } \\
\text { Apukám szintén. Még szegény anyám is, hiá- } \\
\text { ba bekerült, ezt a csöves helyet biztos nem } \\
\text { hagyná." (25 éves nő) }\end{array}$ \\
\hline
\end{tabular}

Forrás: Saját szerkesztés

Ezekben az interjúrészletekben jól követhető, hogy az interjús narratívákban mind a szülő, mind a fiatal elsősorban a családi vagy egyéb, a faluhoz kötő kapcsolatokkal magyarázza a maradást. Az el nem indulás tudatos, vagy kevéssé tudatos okát vagy utólagos magyarázatát a családi kötelékekben jelölték meg.

\section{Mikrotársadalmi szolidaritás}

„Szerintem B. (település) azért jó, mert összetartanak, próbálnak összetartani az emberek, akik így közelebbröl ismerik egymást. Segíteni a másikon. Kölcsönös ez a dolog." (23 éves nö)

A társadalom elsősorban a kapcsolatokon keresztül megvalósuló interakciók segítségével képes a biztonság és a társadalmi egység fokozására (Utasi 2008). A kapcsolathálózat segítségével az egyén különböző erőforrásokat aktivizálhat, ami akár komolyabb válsághelyzetekben is segítséget jelent (Albert - Dávid 2001).

Caplan (1974) szerint a támogató rendszer a következő dolgokban nyújt segítséget: pszichológiai erőforrások mobilizálása érzelmi problémák esetén; megosztja a feladatokat, illetve anyagi, pénzbeli, továbbá szakértői segítséget, útmutatást ad bizonyos helyzetekben. Cobb (1976) szerint a társas támogatás arról is informálja az egyént, hogy szeretik és törődnek vele, értékelik és megbecsülik. Azt is közvetíti a társas támogatás, hogy az egyén tagja az adott közösségnek, mely kölcsönös kötelezettségekből áll. 


\section{TEMATIKUS TANULMÁNYOK - Községekben élő immobil fiatalok}

A közösségeknek, így egy faluközösségnek fontos eleme a szolidaritás. Ez az a terep, ahol kialakul a kölcsönös bizalom, mely elengedhetetlen alapja a szolidaritásnak. Durkheim (1978) kétféle szolidaritásról írt: organikus és mechanikus szolidaritásról. A jóléti társadalmak átalakulásával az organikus szolidaritás egyre inkább veszít mindennapi biztonságot nyújtó szerepéből. Egyre többen fordulnak az erős kötéseik által biztosított mechanikus szolidaritásfajtákra, melyek a tradicionális társadalmakra voltak korábban jellemzőek. Ezekben a társadalmakban a szolidaritás természetes, elvárt. A mindennapi szolidaritás általában elnyújtott reciprocitással történik, melynek ugyancsak a bizalom az alapja. A nagy rétegegyenlőtlenségek nem kedveznek a bizalom kialakulásának (Utasi 2013).

„Az ismerốseim, azok most segítséget nem kérhetek tőlük, mert ők is közmunkások. Inkább a szüleimhez szoktam fordulni segítségért." (48 éves férfi)

Az immobilitásban szerepe lehet annak, hogy a fiatalok mennyire érzik azt, hogy számíthatnak valakire, hogy viszonossági kapcsolatban vannak a falusiakkal, hogy van-e olyan dolog, amivel ő maga hozzá tud járulni a falusiak boldogulásához, azaz van-e egyéni értéke, megbecsültsége a faluban.

Ezeket a jelenségeket a következő interjúkérdések elemzésével lehetett tesztelni:

- „A munkahelyed és a munkatársaid révén el tudsz-e intézni fontos dolgokat a falusiaknak?"

- „Vannak-e olyan rokonaid, barátaid, akikkel tartósan valamilyen viszonosságban vagytok? Akiknek gyakrabban szoktál segíteni ebben-abban, de akikre te is bármikor számíthatsz?"

- „Mennyire érzed úgy, hogy itt te is számíthatsz másokra?”

11. táblázat. Kötelmek és viszonosságok (N=54)

\begin{tabular}{|c|c|c|c|}
\hline & $\begin{array}{l}\text { Igen } \\
\text { (fó) }\end{array}$ & $\begin{array}{l}\text { Nem/nincs } \\
\text { (fó) }\end{array}$ & NT/NV \\
\hline $\begin{array}{l}\text { „A munkahelyed és a munkatársaid révén el tudsz-e } \\
\text { intézni fontos dolgokat a falusiaknak?” }\end{array}$ & 25 & 16 & 13 \\
\hline $\begin{array}{l}\text { „Vannak-e olyan rokonaid, barátaid, akikkel tartósan va- } \\
\text { lamilyen viszonosságban vagytok? Akiknek gyakrabban } \\
\text { szoktál segíteni ebben-abban, de akikre te is bármikor } \\
\text { számíthatsz?” }\end{array}$ & 34 & 15 & 5 \\
\hline $\begin{array}{l}\text { „Mennyire érzed úgy, hogy itt te is számíthatsz mások- } \\
\text { ra?” }\end{array}$ & 43 & 3 & 7 \\
\hline
\end{tabular}

Forrás: Saját szerkesztés 


\section{TEMATIKUS TANULMÁNYOK - Községekben élő immobil fiatalok}

Az interjús kérdésekre adott válaszok alapján világosan kirajzolódik az a támogató hálózat, ami a faluban körülveszi a fiatalokat. Legtöbbjük úgy érzi, hogy számíthat másokra, mások támogatására, és nagyobb részük mondta azt, hogy igen, vannak olyan kapcsolatai a faluban, melyeknél a reciprocitás jelen van a mindennapokban. A munkahellyel egyáltalán rendelkező fiatalok esetén $(n=42)$ láthatjuk, hogy többen vannak azok, akik munkájukhoz kapcsolódóan részt tudnak venni a falusi viszonosságokban, adott esetben el tudnak intézni egy s mást a falusiaknak. Akinek nincs munkahelye, akarva vagy akaratlanul, de könnyen kimaradhat a szolidaritáshálóból is.

A lokális kapcsolatok által nyújtott erőforrásokat a továbbiakban az interjúk során feltárt viszonossági kapcsolatokon, azok irányán és fajtáin keresztül vizsgálom.

A viszonossági kapcsolatok iránya aszerint lett megkülönböztetve, hogy az a családon belülre, családi kapcsolatokra vagy inkább a családon kívüli kapcsolatokra vonatkozik. A válaszok alapján látható, hogy a viszonosságok jellemzők mind a családon belül, mind a családon kívüli kapcsolatoknál oda-vissza.

12. táblázat. A viszonossági kapcsolatok iránya

\begin{tabular}{|l|c|}
\hline \multicolumn{1}{|c|}{ A viszonossági kapcsolat iránya } & Említések száma \\
\hline $\begin{array}{l}\text { Családon belül (jellemzően: unokatestvér, keresztszülő, nagyszü- } \\
\text { lő, testvér, nagybácsi) }\end{array}$ & 26 \\
\hline Családon kívül (jellemzően: barátok, szomszédok) & 21 \\
\hline
\end{tabular}

Forrás: Saját szerkesztés

\section{A viszonossági kapcsolatok fajtái}

A társas kapcsolatok funkcióinak vizsgálata is fontos ahhoz, hogy közelebb jussunk annak megértéséhez, vajon a falusi fiatalok életében milyen szerepet, milyen funkciókat töltenek be azok a kapcsolatok, melyek mindennapjaikat meghatározzák.

A viszonossági kapcsolatok tartalmának, azaz az említett kapcsolatok funkcióinak vizsgálatával tovább pontosíthatjuk a viszonosságok jelentését. Az ide vonatkozó válaszokban tetten érhetők azok a mindennapi viszonosságok, melyek a kölcsönös ismertségen, az egymás „ismerésén”, és az ezeken alapuló bizalmon alapulnak. Ezek a bizalmas és viszonos kapcsolatok sokszor átívelnek a különböző generációkon is.

„Az egyik haverom az édesapámékkal dolgozik együtt és akkor segítjük egymást. Nekik van bolt, ha úgy van, akkor hétvégén is kinyitják, meg ilyesmi. Meg, ha valamit neki kell segíteni, például valahová el kell vinni vagy ilyesmi, azt vissza." (21 éves férfi) 


\section{TEMATIKUS TANULMÁNYOK - Községekben élő immobil fiatalok}

A viszonossági kapcsolatok tartalmát vizsgálva látható, hogy ezeken elsősorban az immateriális javak áramlanak: leggyakrabban az otthoni kisebb-nagyobb munkákban, illetve a mindennapos ügyintézésekben való kölcsönös segítségnyújtás figyelhető meg a fiatalok narratíváiban. Jellemző még a kisebb-nagyobb használati eszközök, illetve a háztartásba szükséges dolgok kölcsönadása, kölcsönvétele, cseréje.

13. táblázat. A viszonosságok fajtái

\begin{tabular}{|l|c|}
\hline \multicolumn{1}{|c|}{ A viszonossági kapcsolat fajtája } & Említések száma \\
\hline $\begin{array}{l}\text { Ügyintézés (hivatalos ügyekben, adóbevallás, autóval szállítás } \\
\text { faluban, falu-város között, bevásárlás, gyógyszerkiváltás, orvoshoz } \\
\text { kísérés/szállítás) }\end{array}$ & 11 \\
\hline Otthoni kisebb-nagyobb munkák (szerelés, javítás, takarítás, favágás) & 11 \\
\hline $\begin{array}{l}\text { Kisebb-nagyobb dolgok kölcsönadása, cseréje (utánfutó, cukor, } \\
\text { babaruha) }\end{array}$ & 7 \\
\hline Emocionális támasz & 4 \\
\hline Tanácsadás & 2 \\
\hline Munka (maszekolás) & 2 \\
\hline Pénz, anyagi & 1 \\
\hline Egyéb (gyermekfelügyelet) & 1 \\
\hline
\end{tabular}

Forrás: Saját szerkesztés

Vannak-e olyan rokonaid, barátaid, akikkel tartósan valamilyen viszonosságban vagytok?

„Persze, a fogadott keresztszüleim, keresztanyám. Figyelj, lelkiekben bármikor mehetek tanácsért, vagy kisírhatom magam vagy hasonló dolgok és szerintem ez oda-vissza müködik. Vagy hogyha mennem kell valahova és akkor lemegyek, hogy eljön-e velem vagy segítene-e bizonyos dolgot elintézni, akkor ott van és segít." (25 éves nö)

„Az unokanővéremnek én is szívesen segítek, meg rá is bármikor számíthatok. Pl. mikor itt laktak a közelben, elmentem segíteni kifesteni a lakást, vagy a szekrényt összeszerelni." (21 éves nö)

„Van. Például unokatestvérem. Ő könyvelőként dolgozik egy irodában és volt, hogy sok mindenben segített már nekünk. Adóbevallást megírni, akkor munkával kapcsolatos intézni valók. Sok tanácsot tud így adni." (23 éves nö) 


\section{TEMATIKUS TANULMÁNYOK - Községekben élő immobil fiatalok}

„Igen, van ilyen. .... Visszatérve a szomszédokra. Többször volt olyan, hogy ha mi elmentünk itthonról és akkor nem értünk haza. Például elmentünk egy lagziba. Nem voltunk itthon éjszaka. És akkor megkérdtük a szomszédot, hogy zárja be a tyúkokat, adjon a kutyának, macskának enni. Ók is így voltak, ugye elmentek a lányához hétvégére, nem volt otthon senki. Azért átmentünk szétnézni, megraktuk a tüzet, hogy ha úgy volt... Egyéb segítséget is, tehát volt ilyen példa, hogy kaszáltunk egy területen és akkor haza kellett hozni a szénát például. És akkor itt elkértük az utánfutót valakitől. Ő ideadta nekünk szívesen, nem fogadott el érte semmit. És legközelebb, mikor hozzánk került a párom, észrevette, hogy nem úgy világít az utánfutó lámpája, ahogy kell. És akkor megszerelte. Tehát ilyen ez a kölcsönösség." (25 éves nő)

„Ha valami a háztartásban elfogy és már mondjuk bezárt a bolt, mondjuk a cukor, akkor megkérdezem a szomszédtól és szó nélkül segít, ad." (22 éves nő)

„Szerintem inkább érzelmi dolgokban szoktuk támogatni egymást a közeli baráti körben, de nyilván mindenkinek vannak meglepetésszerü gondjai, ha meghibásodik valami, vagy tönkremegy valami, azon a területen is szoktunk segíteni egymásnak." (22 éves nő)

Az interjú során adott válaszok lehetővé tették a kiemelt reciprok kapcsolatok meglétének és a mobilitási szándék kapcsolatának vizsgálatát. 49 esetben lehetett azt megnézni, hogy milyen kapcsolat van a fiatal által kinyilvánított mobilitási szándék („Gondolkodtak-e már azon, hogy elköltöznek a faluból?”) és az interjú során pontosan definiált viszonos kapcsolatok megléte között.

14. táblázat. Reciprok kapcsolatok a faluban és mobilitási szándék ( $\mathrm{N}=49)$

\begin{tabular}{|l|c|c|}
\hline \multicolumn{1}{|c|}{ Típusok } & N & \% \\
\hline Van kiemelt reciprok kapcsolata, de menni szeretne. & 13 & 27 \\
\hline Van kiemelt reciprok kapcsolata és nem szeretne menni. & 21 & 43 \\
\hline Nincs kiemelt reciprok kapcsolata és menni szeretne. & 7 & 14 \\
\hline Nincs kiemelt reciprok kapcsolata és nem szeretne menni. & 8 & 16 \\
\hline & 49 & 100 \\
\hline
\end{tabular}

Forrás: Saját szerkesztés

Az interjúk során elmondottakból összeállított adatok szerint a megkérdezettek között az a típus fordult elő leggyakrabban, akiknek van a faluban reciprok kapcsolata és nem áll szándékukban elhagyni a falut. A válaszadók 27\%-a sorolható abba 


\section{TEMATIKUS TANULMÁNYOK - Községekben élő immobil fiatalok}

a típusba, akik annak ellenére szeretnék elhagyni a falut, hogy vannak ott viszonossági kapcsolataik.

A fiatalok elmondásaiból kialakul egy olyan kép, miszerint a falun kívüli fontos kapcsolatok meglétének nincs, viszont a falun belüli reciprok kapcsolatok meglétének inkább van szerepe abban, hogy az adott fiatal a faluban maradt.

Az interjús válaszokból kialakított három változó (Van-e reciprok kapcsolata? Van-e falun kívüli fontos kapcsolata? Van-e mobilitás szándéka?) együttes vizsgálata során azt látjuk, hogy az a típus a leggyakoribb a megkérdezett fiatalok között, akiknek vannak reciprok kapcsolataik, vannak a falun kívül is fontos kapcsolataik, de nincs mobilitási szándékuk. Második leggyakoribb pedig az a típus, akiknek vannak falun belül és falun kívül is értékes kapcsolataik és a terveik között szerepel a falu elhagyása. A falusi kapcsolatok megtartó ereje erősebbnek tűnik tehát, mint a falun kívüli kapcsolatok húzó ereje a vizsgált fiatalok esetében.

15. táblázat. Reciprok kapcsolatok, falun kívüli fontos kapcsolatok és mobilitási szándék $(\mathrm{N}=48)$

\begin{tabular}{|l|c|c|}
\hline \multicolumn{1}{|c|}{ Típusok } & N & \% \\
\hline $\begin{array}{l}\text { Van reciprok kapcsolata, van falun kívüli fontos kapcsolata, nincs } \\
\text { mobilitási szándéka }\end{array}$ & 20 & 42 \\
\hline $\begin{array}{l}\text { Van reciprok kapcsolata, van falun kívüli fontos kapcsolata, van } \\
\text { mobilitási szándéka }\end{array}$ & 11 & 23 \\
\hline $\begin{array}{l}\text { Nincs reciprok kapcsolata, van falun kívüli fontos kapcsolata, nincs } \\
\text { mobilitási szándéka }\end{array}$ & 5 & 13 \\
\hline $\begin{array}{l}\text { Nincs reciprok kapcsolata, van falun kívüli fontos kapcsolata, van } \\
\text { mobilitási szándéka }\end{array}$ & 2 & 4 \\
\hline $\begin{array}{l}\text { Van reciprok kapcsolata, nincs falun kívüli fontos kapcsolata, nincs } \\
\text { mobilitási szándéka }\end{array}$ & 2 & 4 \\
\hline $\begin{array}{l}\text { Van reciprok kapcsolata, nincs falun kívüli fontos kapcsolata, van } \\
\text { mobilitási szándéka }\end{array}$ & 1 & 2 \\
\hline $\begin{array}{l}\text { Nincs reciprok kapcsolata, nincs falun kívüli fontos kapcsolata, } \\
\text { nincs mobilitási szándéka }\end{array}$ & 48 & 100 \\
\hline $\begin{array}{l}\text { Nincs reciprok kapcsolata, nincs falun kívüli fontos kapcsolata, } \\
\text { nincs mobilitási szándéka }\end{array}$ & 10 \\
\hline
\end{tabular}

Forrás: Saját szerkesztés 


\section{TEMATIKUS TANULMÁNYOK - Községekben élő immobil fiatalok}

\section{Összegzés}

A kutatásba kerülő fiatalok interjús válaszai alapján az a kép rajzolódik ki, hogy személyes kapcsolathálózatukban az erős, elsősorban közeli családtagokból, rokonokból álló kapcsolatok vannak túlsúlyban. A fiatalok zöme még szüleikkel él, akkor is, ha már saját családot alapított vagy élettársi, illetve párkapcsolatban él.

A gyenge kötések közül leginkább a volt iskolatársak, osztálytársak, egyetemi csoporttársak vannak jelen a fiatalok networkjében. A helyi oktatási intézményeknek nagy szerepe van a barátságok kialakulásának terepeként. Sok fiatalnak a helyi intézményekben eltöltött időhöz kötődnek a jelenlegi falusi baráti kapcsolatai.

A falun belüli munkahelyi kapcsolatok, szomszédok, ismerősök nem általános aktorai a megkérdezettek kapcsolathálózatának.

A helyi kapcsolatok visszahúzó erejét mutatja, hogy azok a fiatalok, akiknek van a falun kívül kapcsolata, azokra sem jellemző, hogy szeretnének elköltözni. A falun kívüli kapcsolatoknak úgy tűnik, nincs motiváló ereje a mobilitási szándékot illetően.

A binding és bonding típusú kapcsolatok a gyakoribbak a vizsgált fiataloknál, ritkább a bridging típusú kapcsolatok jelenléte a személyes kapcsolathálózatukban. Ez azt jelenti, hogy az egyéni networkre általában a homogenitás jellemző: egyrészt erős kapcsolatokat tartalmaz, mely az emocionális és bizalmas kapcsolatok túlsúlyát jelenti, másrészt egyfajta zártságot is jelez, hiszen a bonding típusú kapcsolatokra is a homogenitás jellemző, az ide sorolható kapcsolatok közösen birtokolják a különböző típusú erőforrásokat. A munkatársi, szomszédsági, lazább ismeretségi kapcsolatok ritkább előfordulása, a faluban élő és elérhető kapcsolatok erőssége, az interjúkban is jól megjelenő mikrotársadalmi szolidaritás azt is jelentheti egyúttal, hogy az erős kapcsolatokon keresztül áramló erőforrások sokkal inkább szolgálják a fiatalok mindennapos boldogulását, mint a gyengébb, bridging típusú kötések. Ez a jelenség azonban azt a veszélyt is magában hordozza, hogy egy szűk körben megtermelődő erőforrás áll rendelkezésre, melyek könnyen el is fogyhatnak. És ha nincsenek hídszerű kötések, kapcsolódások, akkor nincsenek olyan új muníciók, melyek az erőforrások újrateremtését segítik elő.

Összességében az interjúk során adott válaszok alapján úgy tűnik, hogy a megkérdezett fiatalok esetén a falun kívüli kapcsolatoknak nincs motiváló ereje a mobilitási szándékot illetően, viszont erős megtartó ereje van a falusi viszonosságoknak.

Kmetty-Koltai (2016) szerint, ha a kapcsolatok a csoportokon belül sűrűsödnek és kifelé bezáródnak, azok negatív következményekkel járhatnak. A szerzők Portes-re hivatkozva azt állítják, hogy a túl erős kapcsolatháló konformitást eredményezhet és a csoport visszahúzó képességét növelheti (Portes 1998).

„Viszonylag amúgy azt gondolom, hogy a b-i (település) nép kicsit ilyen bezárt. A b-iek, azok b.-iek. Szerintem ez minden faluban megfigyelhető." (24 éves nö) 


\section{TEMATIKUS TANULMÁNYOK - Községekben élő immobil fiatalok}

Az interjúk során adott válaszokból úgy tűnik, hogy a megkérdezett falusi fiatalokkal éppen ez történik: erős és támogató, elsősorban a falusiakból álló kapcsolatrendszerük útját állja mobilitásuknak.

\section{Irodalom}

Albert F. - Dávid B. (1998): A barátokról. In: Kolosi T. - Tóth I. G. - Vukovich Gy. (szerk.): Társadalmi Riport 1998. Budapest

Albert F. - Dávid B. (2001): Ha elszakad a háló... A hajléktalanság kapcsolathálózati megközelítésben. Új Mandátum Kiadó, Budapest

Albert F. - Dávid B. (2003): Az emberi kapcsolatok alakulása Magyarországon a XX. század utolsó évtizedében. Budapest: TÁRKI, http://www.tarki.hu/adatbank-h/ kutjel/pdf/a592.pdf Utolsó letöltés ideje: 2019. augusztus 18.

Albert F. - Dávid B. (2007): Embert barátjáról: A barátság szociológiája. Századvég, Budapest

Albert, F. - Dávid B. (2012): Az interperszonális kapcsolathálózati struktúra átrendeződése Magyarországon. In: Kovách I. et al. (szerk.): Társadalmi integráció a jelenkori Magyarországon. Argumentum Kiadó, Budapest

Albert F. - Dávid B. (2015): Mikromiliő integrációs megközelítésben. A személyes kapcsolatokra vonatkozó eddigi kutatás eredményeinek áttekintése. DoI: 10.18030/ socio.hu.2015.4.1. http://real.mtak.hu/33610/1/albert1.pdf. Utolsó letöltés ideje: 2019. augusztus 18.

Albert F. - Dávid B. - Gerő M. - Hajdu G. (2017): Kapcsolathálózati tipológia és társadalmi integráció. In: Kovách I. (szerk.): Társadalmi integráció. Belvedere, Szeged

Angelusz R. - Tardos R. (1998): A kapcsolathálózati erőforrások átrendeződésének tendenciái a kilencvenes években. In: Kolosi T. - Tóth I. Gy. - Vukovich Gy. (szerk): Társadalmi Riport 1998., Budapest

Angelusz R. - Tardos R. (2006): Hálózatok a magyar társadalomban. In: Kovách I. (szerk.): Társadalmi metszetek. Napvilág Kiadó, Budapest

Bidard, C. (2006): Social networks and social integration panel. A longitudinal survey. The process of entering adult life, starting work and developing social networks. https://halshs.archives-ouvertes.fr/halshs-00164797v1 Utolsó letöltés ideje: 2019. augusztus 18.

Bourdieau, P. (1986): Distinction. A Social Critique of the Judgement of Taste. Routledge and Kegan Paul, London

Caplan, G. (1974): Support Systems and Community Mental Health: Lectures on Concept Development. Behavioural Publications, New York 


\section{TEMATIKUS TANULMÁNYOK - Községekben élő immobil fiatalok}

Cobb, S. (1976): Social Support as a Moderator of Life Stress. Psychosomatic Medicine, 38(5). 300-314.

Coleman, J. S. (1988): Social Capital in the Creation of Human Capital. American Journal of Sociology 94, 95-120.

Dávid B. - Huszti É. - Vajda K. (2012): Strong tie, weak tie and in-betweens: a continuous measure of tie strength based on contact diary datasets. PROCEDIA - SOCIAL AND BEHAVIORAL SCIENCES 79:(6). 38-61.

Dávid B. - Lukács Á. - Huszti É. - Barna I. (2017): Kapcsolati napló - pluszok és mínuszok. Új módszer az egocentrikus kapcsolathálózat kutatásában. In: Kovách I. (szerk.): Társadalmi integráció, Belvedere, Szeged

Durkheim, E. (1978): A társadalmi tények magyarázatához. KJK, Budapest

Fazekas A. - Nagy Á. - Monostori K. (2018): „Bú, baj, bánat messze szalad!” Életesemények, problémák, mobilitás, migráció. In: Nagy Á. (szerk.): Margón kívül. Magyar ifjúságkutatás 2016. Excenter Kutatóközpont, Budapest

Gerő M. - Hajdu G. (2015): Az egyéni kapcsolathálók nagysága, heterogenitása és a társadalmi integráció Magyarországon. DoI: 10.18030/socio.hu.2015.4.12 https://socio.hu/uploads/files/2015_4/gero_hajdu.pdf Utolsó letöltés ideje: 2019. augusztus 18.

Granovetter, M. S. (1973): The Strenght of Weak Ties. American Journal of Sociology, 78:1360-1380.

Granovetter, M. S. (1974): Getting a Job. Study of Contacts and Careers. Harvard University Press, Cambrigde

Gyarmati A. (2009): Hogyan verjünk hidat az idősekhez? Az ötven év fölöttiek kommunikációs és kapcsolathálózatának néhány jellemzője. http://www.infonia.hu/ digitalis_folyoirat/2009_4/2009_4_gyarmati_hid.pdf Utolsó letöltés ideje: 2019. augusztus 18.

Huszti É. (2015): Megismer-hetem. A személyes kapcsolathálózat feltárásának új formája: kapcsolati napló. Debreceni Egyetemi Kiadó, Debrecen

Kmetty Z. - Koltai J. (2016): Státuszelérés, társas támogatás, társadalmi törésvonalak. A kapcsolathálózati integráció aspektusai. socio.hu 2016/3 DOI:10.18030/ soci.hu.2016.3.1 https://socio.hu/uploads/files/2016_3/kmetty_koltay.pdf Utolsó letöltés ideje: 2019. augusztus 18.

Koltai J. - Nemes D. (2017): A lakóhely hatása a társadalmi kapcsolatokra. In: Kovách I. (szerk.): Társadalmi integráció, Belvedere, Szeged

Kopasz M. - Szántó Z. - Várhalmi Z. (2008): A magyar háztartások tagjainak kapcsolatháló-dinamikája 1992 és 2007 között. In: Kolosi T. - Tóth I. Gy. (szerk.): Újratervezés. Életutak és alkalmazkodás a rendszerváltás évtizedeiben. TÁRKI, Budapest 


\section{TEMATIKUS TANULMÁNYOK - Községekben élő immobil fiatalok}

Lin, N. (2008): A network theory of social capital. In: Castiglione, D. - van Deth, J. W. - Wolleb, G. (edit.): The Handbook of Social Capital. Oxford University Press, Oxford

Portes, A. (1998): Social Capital: Its Origins and Applications in Modern Sociology. Annual Review of Sociology, 24, 1-24. http://dx.doi.org/10.1146/annurev. soc.24.1.1.

Utasi Á. (1990): Baráti kapcsolatok. In: Andorka R. - Kolosi T. - Vukovich Gy. (szerk.): Társadalmi Riport 1990. TÁRKI, Budapest

Utasi Á. (1991): Társas kapcsolatok. Gondolat Könyvkiadó, Budapest

Utasi Á. (2002a): A bizalom hálója. Új Mandátum Könyvkiadó, Budapest

Utasi Á. (2002b): A társadalmi integráció és a szolidaritás alapjai: a bizalmas kapcsolatok. Századvég, 24. szám http://www.szazadveg.hu/files/kiadoarchivum/24utasi.pdf Utolsó letöltés ideje: 2019. augusztus 18.

Utasi Á. (2008): Éltető kapcsolatok - A kapcsolatok hatása a szubjektív életminőségre. Új Mandátum Könyvkiadó, Budapest

Utasi Á. (2013): Kötelékben. Szolidaritás-hálók és közélet. MTA Társadalomtudományi Kutatóközpont, Belvedere, Szeged

Vastag Z. - Huszár Á. (2008): Kapcsolatszegény - Aki szegény, az a legszegényebb? In: Statisztikai Szemle, 86 (12), 1103-1125. 